\title{
A Systematic Literature Review of Syphilitic Hepatitis in Adults
}

\author{
Jiaofeng Huang ${ }^{1}$, Su Lin ${ }^{1}$, Bo Wan ${ }^{2}$ and Yueyong Zhu*1 \\ ${ }^{1}$ Liver Research Center of the First Affiliated Hospital of Fujian Medical University, Fuzhou, Fujian, China; \\ ${ }^{2}$ Institute of Neurology, University College London, London, UK
}

\begin{abstract}
Syphilitic hepatitis in adults is not frequently found in the population and is easily misdiagnosed. The incidence of viral hepatitis is increasing year by year, concomitantly increasing the importance of obtaining a systematic understanding of the clinical features and treatment strategies for this disease. There is, however, a lack of published definitive data regarding the clinical characteristics, diagnosis and standard treatment options for this disease. Searches were made using the MEDLINE database of PubMed and OVID for syphilitic hepatitis publications from 1951 to 2017 in an attempt to analyze and summarize the clinical characteristics.
\end{abstract}

Citation of this article: Huang J, Lin S, Wan B, Zhu Y. A systematic literature review of syphilitic hepatitis in adults. J Clin Transl Hepatol 2018;6(3):306-309. doi: 10.14218/JCTH.2018.00003.

\section{Introduction}

Syphilis is a sexually transmitted infection induced by the spirochete Treponema pallidum, which has a huge impact on people's physical and mental health. In its natural course, the disease progresses from primary syphilis to secondary syphilis and tertiary syphilis if left untreated. A chancre is often seen in primary syphilis. Secondary syphilis is characterized by a distinctive rash, while tertiary syphilis is typified by neurosyphilis, cardiovascular syphilis or gummatous syphilis. ${ }^{1}$

An infectious venereal disease with multiple organs involved, syphilis has been described as "the great imitator". ${ }^{2,3}$ The liver is one of the organs that can be affected. ${ }^{4}$ Liver disease due to syphilis infection has rarely been reported and little is known about syphilitic hepatitis (SH). Maryam et al. ${ }^{5}$ reported a case of a male with $\mathrm{SH}$ who showed multiple liver lesions, while the case published by Aggarwal et al. ${ }^{6}$ presented with raised alkaline phosphatase levels. Syphilis, especially in its early stages, is often asymptomatic and easily misdiagnosed. $^{7}$ The increasing incidence of syphilis will result in more $\mathrm{SH}^{8}$ therefore it is important to improve the understanding of this disease. Fehér et al. ${ }^{9}$ reported 17 pathologicallyconfirmed cases of SH from 175 patients with syphilis, in

Keywords: Syphilis; Hepatitis; Liver enzyme; Granuloma.

Abbreviations: ALP, alkaline phosphatase; ALT, alanine transaminase; AST, aspartate aminotransferase; GGT, gamma-glutamyl transpeptidase; HCV, hepatitis $\mathrm{C}$ virus; $\mathrm{SH}$, syphilitic hepatitis; TBIL, total bilirubin.

Received: 6 January 2018; Revised: 12 February 2018; Accepted: 3 March 2018 *Correspondence to: Yueyong Zhu, Liver Research Center of the First Affiliated Hospital of Fujian Medical University, Fuzhou, Fujian 350001, China. Tel: +86-59187981656, Fax: +86-591-87982526, E-mail: zhuyueyong@fjmu.edu.cn
1975. However, coinfection with hepatitis C virus cannot be ruled out from this population. In 2004, Mullick et al. ${ }^{10}$ defined $\mathrm{SH}$ in detail, however, the reports of this disease are still rare.

There is still a lack of definitive data published about the clinical characteristics, diagnosis and standard treatments of $\mathrm{SH}$. To this end, we searched the MEDLINE database for SH publications from 1951 to 2017, analyzing and summarizing the clinical characteristics through a systematic literature review.

\section{Methods}

We searched the MEDLINE database of PubMed and OVID for case reports, case series and descriptions of adult-onset $\mathrm{SH}$. The electronic databases were searched for publications up to January 2017 with the following MeSH terms: "syphilitic hepatitis", "syphilis and liver", "syphilis and jaundice", "syphilis and hepatitis". We also manually searched the references and related reviews of each included study for other possible citations. The searches were restricted to English-language publications.

\section{Results}

Finally, a total of 73 articles containing 144 cases of SH in adults with medical records were discovered $2,3,5,6,10-78$ (Fig. 1). The earliest article dated back to $1951^{78}$ and the latest was published in $2016 .{ }^{11}$ The largest contribution came from the study by Jung et al. ${ }^{36}$ with 19 patients. Only 129 of the total 144 patients had complete demographic information. The mean age of the 129 cases with information available was 40.5 years, ranging from 14 to 76 . The majority were male (130/ $144,90.3 \%)$, with a sex ratio of $9.3(130 / 14$, male/female). The number of homosexual patients were 56 out of 103 recorded $(54.4 \%)$, and all of them were men who had sex with men. Only 127 of the 129 patients had provided information on human immunodeficiency virus (HIV) infection. The number of patients coinfected with HIV and syphilis were 78 out of 127 with information available (61.4\%). The stage of syphilis was recorded for all of the 144 patients, and included $128(88.9 \%)$ with early syphilis (including primary and secondary syphilis), 7 (4.9\%) with latent syphilis, and 9 (6.3\%) with tertiary syphilis.

A total of 97 cases had detailed clinical data available. The symptoms of $\mathrm{SH}$ were nonspecific in nature. Rashes were the most common clinical manifestations of SH (74/97, 77.9\%), followed by fatigue or poor appetite $(55 / 97,56.7 \%)$, icterus $(34 /$ $97,35.1 \%)$, fever $(25 / 97,25.8 \%)$, weight loss $(22 / 97,22.7 \%)$, abdominal pain $(21 / 97,21.6 \%)$, phallodynia $(13 / 97,13.4 \%)$, 
Huang J. et al: Syphilitic hepatitis

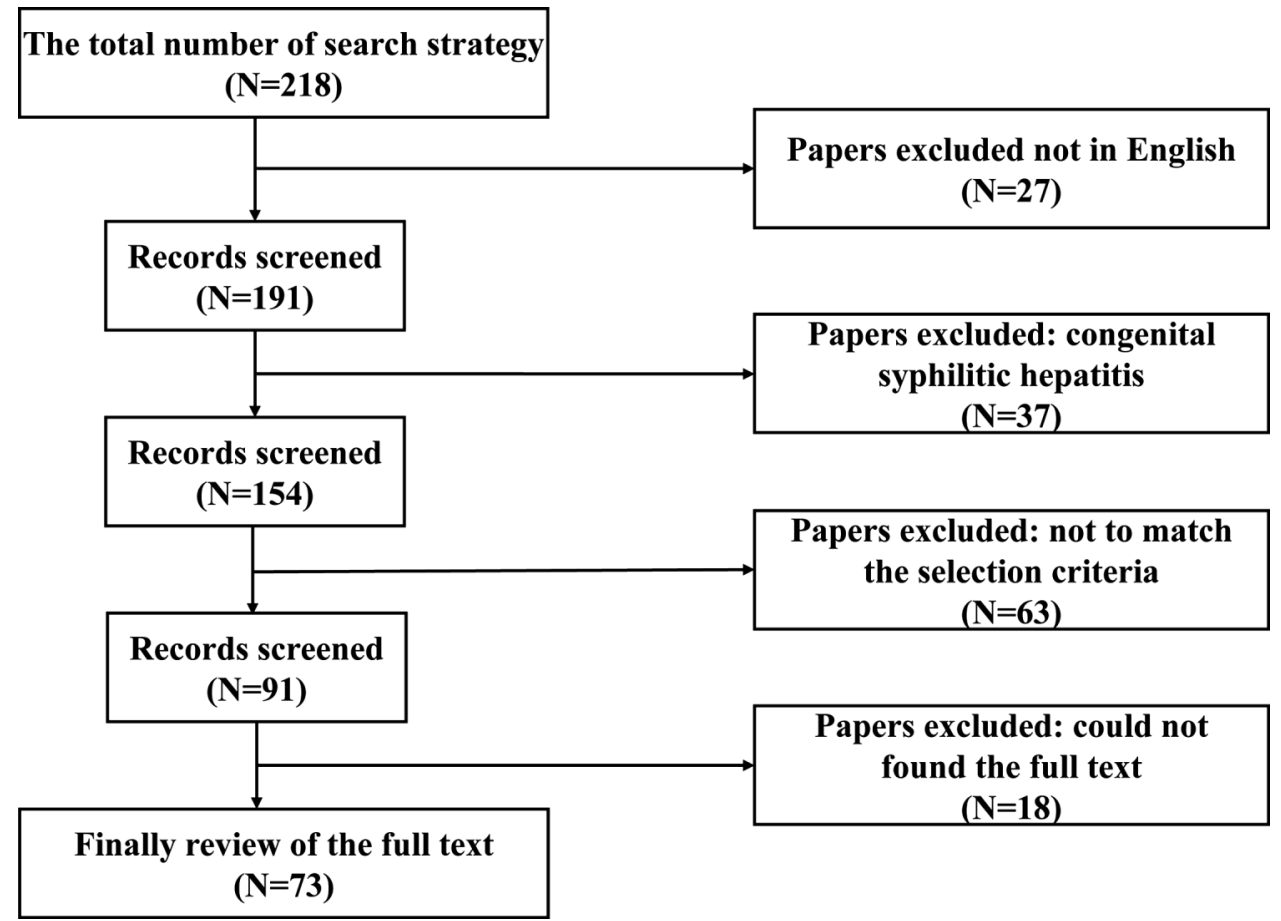

Fig. 1. A flow chart of the procedure followed for this systematic review.

sore throat $(8 / 97,8.2 \%)$, headache $(7 / 97,7.2 \%)$ and arthralgia or myodynia $(6 / 97,6.2 \%)$. In addition, physical examination revealed cases of hepatomegaly $(52 / 97,53.6 \%)$, lymphadenopathy $(30 / 97,30.9 \%)$, splenomegaly $(14 / 97$, $14.4 \%)$ and uveitis $(8 / 97,8.2 \%)$.

Information of the liver laboratory values was available for 99 out of the 144 patients (68.8\%). The mean and $95 \%$ confidence interval $(\mathrm{CI})$ of laboratory values have been summarized in the diagram below (Fig. 2). The mean for the laboratory values were $82.5 \mu \mathrm{mol} / \mathrm{L}$ (total bilirubin, TBIL), $314.5 \mathrm{U} / \mathrm{L}$ (alanine aminotransferase, ALT), $253.0 \mathrm{U} / \mathrm{L}$ (aspartate aminotransferase, AST), $684.5 \mathrm{U} / \mathrm{L}$ (alkaline phosphatase, ALP) and $561.8 \mathrm{U} / \mathrm{L}$ (gamma-glutamyl transpeptidase, GGT). We found an obvious rise in ALP and GGT outside of the normal ranges and slight elevations of ALT and TBIL.

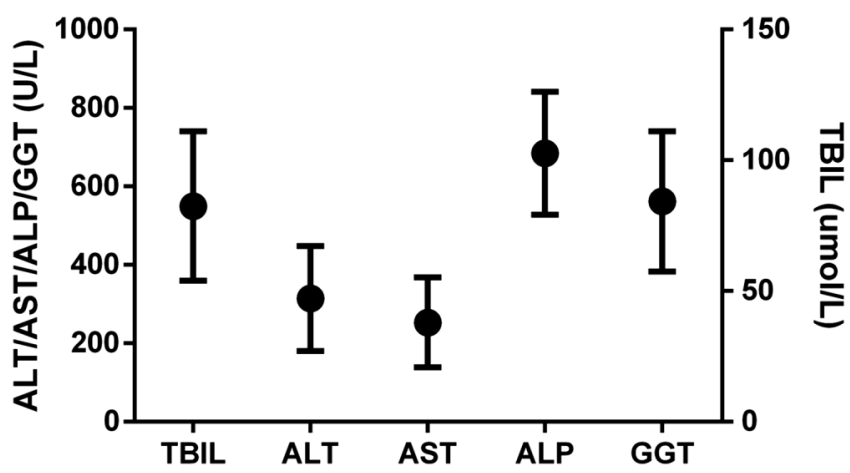

Fig. 2. The mean and $95 \% \mathrm{CI}$ of laboratory values. Abbreviations: ALP, alkaline phosphatase; ALT, alanine transaminase; AST, aspartate aminotransferase; CI, confidence interval; GGT, gamma-glutamyl transpeptidase; TBIL, total bilirubin.
A total of 55 cases had liver biopsy taken. The hallmark histopathological features found in the hepatic tissue included inflammatory cell infiltration of portal areas or hepatic lobules $(48 / 55,87.2 \%)$, hepatocellular necrosis $(25 / 55,45.5 \%)$, granuloma with multinucleated giant cells $(11 / 55,20 \%)$, cholestasis $(27 / 55,49.0 \%)$ and fibrosis (10/55, 18.2\%). Immunohistochemical staining or Warthin-Starry staining were performed in 28 cases. In 19 of the 28 cases, treponema spirochetes were visualized in liver tissue, 15 of which were discovered by immunohistochemical staining and 4 by Warthin-Starry stain.

All the patients received antibiotic therapy. Among the 144 cases, 129 took intramuscular or intravenous penicillin therapy, 5 took oral doxycycline, 7 had oral amoxicillin hydrate and 3 used ceftriaxone. Jarisch-Herxheimer reaction occurred in 7 patients, with 6 of them responding to penicillin and one to amoxicillin hydrate treatment. All patients responded well to treatment.

\section{Discussion}

This systematic review showed that liver damage usually occurred in early syphilis, which was easily missed as a diagnosis because of the nonspecific nature of presenting symptoms. The results also found that $\mathrm{SH}$ was more often diagnosed in men, especially those who had sex with men, which could be linked to the route of sexual transmission. There were four large studies carried out to explore the relationship between $\mathrm{SH}$ and autoimmune deficiency syndrome, with a total of 54 patients. ${ }^{34,36,48,49}$ The studies showed that $\mathrm{SH}$ is common in HIV-positive patients with syphilis infection. Syphilis should be included in the differential diagnosis of HIV patients presenting with liver test abnormalities, rash and/or sexual risk factors. Liver damage is very common in HIV-infected patients 
because of their use of antiretroviral therapy, opportunistic infections and increased malignancy rates. ${ }^{10}$ In light of this, clinicians should try to maintain a broad list of differential diagnoses.

The clinical manifestations of $\mathrm{SH}$ in adults are often nonspecific and multifaceted. Rashes, fatigue or poor appetite, hepatomegaly and icterus were the most common. The rashes often presented as multiple nonpruritic, erythematous, nonconfluent maculopapular lesions, generally concentrated on the trunk, palms and soles of the feet. Hepatosplenomegaly is often found on physical examination or imaging. The laboratory tests of SH will show abnormal liver enzymes with a marked increase of ALP and GGT, in contrast to a mild elevation in ALT or AST levels. Histological features of $\mathrm{SH}$ include bile duct inflammatory infiltration, which may be linked to the elevated blood ALP and GGT levels. Hepatic granuloma is another feature of $\mathrm{SH}^{79}$ It is very difficult to identify the spirochetes in liver tissue among these patients. Only 19 patients showed spirochetes in the liver tissue on immunohistochemical staining $11,16,24$ or Warthin-Starry staining. ${ }^{43,51,52}$

This is the first systematic review of $\mathrm{SH}$. The results will help clinicians better understand this disease. The main limitations of this study were the retrospective design and the heterogeneous sources of the data. The heterogeneity and lack of data may cause bias.

\section{Conclusions}

The clinical characteristics of SH were its nonspecific presentation, elevated liver enzymes, especially ALP and GGT and bile duct inflammation or granuloma formation as seen by hepatic histopathology. Together, these facets of $\mathrm{SH}$ can provide some direction for clinicians regarding the approach to diagnosis of this disease.

\section{Acknowledgments}

We thank Bharat Velani, MD, PhD, from University College London (UK) for editing the English grammar of a draft of this manuscript. This study was funded by the Science and Technology Project of Fujian Education Department (JA15207) and Fujian Natural Science Foundation (2016Y0040, 2017J01187) and Fujian Medical Innovation Project (2016-cx-033).

\section{Conflict of interest}

The authors have no conflict of interests related to this publication.

\section{Author contributions}

Independently carried out the reference selection and data selection, performed analysis and interpretation of the findings, and drafted the article $(\mathrm{JH})$, designed the study (BW), manuscript preparation (SL), served as third investigator for resolution of discrepancies through a consensus meeting $(\mathrm{YZ})$, revised the final article for important intellectual content (SL, YZ).

\section{References}

[1] Dupin N, Farhi D. Syphilis. Presse Med 2013;42:446-453. doi: 10.1016/j. Ipm.2012.09.024.
[2] Suzuki I, Orfanidis N, Moleski S, Katz LC, Kastenberg D. The "great imitator" presents with abnormal liver enzymes. The Medicine Forum 2009;11:17. doi: 10.29046/TMF.011.1.015.

[3] Sabbatani S, Manfredi R, Attard L, Chiodo F. The "great imitator" syphilis as causative agent of isolated, concurrent, acute hepatitis and meningitis. Infect Dis Clin Pract 2005;13:261-264. doi: 10.1097/01.idc.0000168478. 73470.69 .

[4] Goodridge HF. A case of acute atrophy of the liver complicating early secondary syphilis. Br Med J 1871;1:609-610. doi: 10.1136/bmj.1.545.609.

[5] Keshtkar-Jahromi M, Rassaei N, Bruno MA, Maneval ML, Whitener CJ. Photo quiz. a 59-year-old man with multiple liver lesions, rash, and uveitis. Clin Infect Dis 2016;62:82-83. doi: 10.1093/cid/civ754.

[6] Aggarwal SK, Radhakrishnan S. Syphilitic hepatitis: Look for raised alkaline phosphatase level. Med J Armed Forces India 2016;72:192-193. doi: 10. 1016/j.mjafi.2015.11.011.

[7] Hook EW Rd. Syphilis. Lancet 2017;389:1550-1557. doi: 10.1016/S01406736(16)32411-4.

[8] Patton ME, Su JR, Nelson R, Weinstock H. Primary and secondary syphilisUnited States, 2005-2013. MMWR Morb Mortal Wkly Rep 2014;63:402-406.

[9] Fehér J, Somogyi T, Timmer M, Józsa L. Syphilitic hepatitis: clinical, immunological and morphological aspects. Acta Med Acad Sci Hung 1975;32:155-161.

[10] Mullick CJ, Liappis AP, Benator DA, Roberts AD, Parenti DM, Simon GL. Syphilitic hepatitis in HIV-infected patients: a report of 7 cases and review of the literature. Clin Infect Dis 2004;39:e100-e105. doi: 10.1086/425501.

[11] Rubio-Tapia A, Hujoel IA, Smyrk TC, Poterucha J]. Emerging secondary syphilis presenting as syphilitic hepatitis. Hepatology 2017;65:2113-2115. doi: 10.1002/hep.28974.

[12] Batteiger T. Painless jaundice and transaminitis as a presentation of secondary syphilis. 2016 STD Prevention Conference 2016. Available from: https://cdc.confex.com/cdc/std2016/webprogram/Paper37674.html.

[13] Vukšić Polić M1, Plužarić V, Kuric I. Syphilitic hepatitis: rare or just unrecognized? Acta Dermatovenerol Croat 2015;23:70-71.

[14] Pilozzi-Edmonds L, Kong LY, Szabo J, Birnbaum LM. Rapid progression to gummatous syphilitic hepatitis and neurosyphilis in a patient with newly-diagnosed HIV. Int J STD AIDS 2015;26:985-987. doi: 10.1177/0956462414564401.

[15] Mulder CJ, Cho RS, Harrison SA, Cebe K, Francis JM. Syphilitic hepatitis uncommon presentation of an old scourge. Mil Med 2015;180:e611-e613. doi: $10.7205 /$ MILMED-D-14-00530.

[16] Khambaty M, Singal AG, Gopal P. Spirochetes as an almost forgotten cause of hepatitis. Clin Gastroenterol Hepatol 2015;13:A21-A22. doi: 10.1016/j.cgh. 2014.09.043.

[17] Ishiwatari A, Hasegawa J, Hoshino Y, Kaga T, Abe Y, Wakai S. Simultaneous nephrotic syndrome and hepatitis in secondary syphilis: case report and review of the literature. CEN Case Rep 2015;4:223-227. doi: 10.1007/ s13730-015-0173-2.

[18] Clement ME, Okeke NL, Hicks CB. Fever and rash in a patient with hepatitis. JAMA 2015;314:400-401. doi: 10.1001/jama.2015.3401.

[19] Yoshikawa K, Aida Y, Seki N, Miyazaki T, Itagaki M, Ishiguro H, et al. Early syphilitic hepatitis concomitant with nephrotic syndrome followed by acute kidney injury. Clin J Gastroenterol 2014;7:349-354. doi: 10.1007/s12328014-0499-x.

[20] Sprenger K, Furrer H. Chameleons everywhere. BM] Case Rep 2014;2014. doi: 10.1136/bcr-2014-205608

[21] Solari PR, Jones C, Wallace MR. Hepatic lesions with secondary syphilis in an HIV-infected patient. Case Rep Med 2014;2014:604794. doi: 10.1155/ 2014/604794

[22] Hagen CE, Kamionek M, McKinsey DS, Misdraji J. Syphilis presenting as inflammatory tumors of the liver in HIV-positive homosexual men. Am J Surg Pathol 2014;38:1636-1643. doi: 10.1097/PAS.0000000000000264.

[23] Gaslightwala I, Khara HS, Diehl DL. Syphilitic gummas mistaken for liver metastases. Clin Gastroenterol Hepatol 2014;12:e109-e110. doi: 10.1016/ j.cgh.2014.04.022.

[24] Fielding CM, Angulo P. Right upper-quadrant pain in a patient with drug abuse, secondary syphilis and occult hepatitis B virus. Med Princ Pract 2014;23:471-474. doi: 10.1159/000360401.

[25] Bork JT, Macharia T, Choi J, Gilliam BL, Buchwald UK. Syphilitic hepatitis treated with doxycycline in an HIV-infected patient and review of the literature. Sex Transm Dis 2014;41:507-510. doi: 10.1097/OLQ.0000000000000143.

[26] Baveja S, Garg S, Rajdeo A. Syphilitic hepatitis: an uncommon manifestation of a common disease. Indian J Dermatol 2014;59:209. doi: 10.4103/00195154.127711.

[27] Palacios $R$, Navarro $F$, Narankiewicz $D$, Marcos $M$, Jiménez-Oñate $F$, de la Torre J, et al. Liver involvement in HIV-infected patients with early syphilis. Int J STD AIDS 2013;24:31-33. doi: 10.1177/0956462412472316.

[28] Malincarne L, Pasticci MB, Angeli G, Baldelli F, De Socio GV. Syphilis as a diagnosis of liver abnormalities in HIV. Scand J Infect Dis 2013;45:703705. doi: 10.3109/00365548.2013.793819.

[29] Lee M, Wang C, Dorer R, Ferguson L. A great masquerader: acute syphilitic hepatitis. Dig Dis Sci 2013;58:923-925. doi: 10.1007/s10620-012-2322-1. 
[30] Kim M, Echevarria L, Savilo E. Answer to June 2013 Photo Quiz. J Clin Microbiol 2013;51:2016. doi: 10.1128/JCM.00703-12.

[31] da Silva BA, Soi TS, Cameron D, Karikkineth AC, Williams RB. Syphilis, hepatitis, and pancreatitis: is the uncommon becoming common in the $\mathrm{HIV}(+)$ patient? Case Rep Infect Dis 2013;2013:293823. doi: 10.1155/2013/293823.

[32] Aggarwal A, Sharma V, Vaiphei K, Duseja A, Chawla YK. An unusual cause of cholestatic hepatitis: syphilis. Dig Dis Sci 2013;58:3049-3051. doi: 10. 1007/s10620-013-2581-5.

[33] Adachi E, Koibuchi T, Okame M, Sato H, Kikuchi T, Koga M, et al. Liver dysfunction in patients with early syphilis: a retrospective study. J Infect Chemother 2013;19:180-182. doi: 10.1007/s10156-012-0440-5.

[34] Manavi K, Dhasmana D, Cramb R. Prevalence of hepatitis in early syphilis among an HIV cohort. Int J STD AIDS 2012;23:e4-e6. doi: 10.1258/ijsa. 2009.009386.

[35] Lin H, Russo P, Rook M. Secondary syphilitic hepatitis in a 17-year-old girl. J Pediatr Gastroenterol Nutr 2012;55:e134-e135. doi: 10.1097/MPG. Ob013e31824177cf.

[36] Jung N, Kümmerle T, Brengelmann SD, Gielen J, Lehmann C, Wyen C, et al. Liver involvement in HIV-infected patients diagnosed with syphilis. Infection 2012;40:543-547. doi: 10.1007/s15010-012-0264-3.

[37] Hosein SR. Hepatitis caused by syphilis. Canadian AIDS Treatment Information Exchange 2012. Available from: http://www.thebodypro.com/content/ 69370/hepatitis-caused-by-syphilis.html.

[38] Filho FB, Santos MVPQ, Perez VPF, Jaber NM, Alves AO, Azulay DR, et al. Cutaneous and visceral syphilis: unusual presentation. DST-J bras Doenças Sex Transm 2012;24:195-197. doi: 10.5533/DST-2177-8264-201224310.

[39] Canney M, Liu E, Vonthethoff L, Weatherall C, Ong S. Nephrotic syndrome and hepatitis due to acquired syphilis: an uncommon presentation of a reemerging disease. NDT Plus 2011;4:67-70. doi: 10.1093/ndtplus/sfq194.

[40] Adachi E, Koibuchi T, Okame M, Sato H, Imai K, Shimizu S, et al. Case of secondary syphilis presenting with unusual complications: syphilitic proctitis, gastritis, and hepatitis. J Clin Microbiol 2011;49:4394-4396. doi: 10 1128/JCM.01240-11.

[41] Rutland E, Harindra VK. Syphilis: an important cause of infectious hepatitis Int J STD AIDS 2010;21:215-216. doi: 10.1258/ijsa.2009.009031.

[42] Miura H, Nakano M, Ryu T, Kitamura S, Suzaki A. A case of syphilis presenting with initial syphilitic hepatitis and serological recurrence with cerebrospinal abnormality. Intern Med 2010;49:1377-1381. doi: 10.2169/internalmedicine. 49.3414.

[43] Kim GH, Kim BU, Lee JH, Choi YH, Chae HB, Park SM, et al. Cholestatic hepatitis and thrombocytosis in a secondary syphilis patient. J Korean Med Sci 2010;25:1661-1664. doi: 10.3346/jkms.2010.25.11.1661.

[44] Bjekić M, Marković M, Sipetić S. Early syphilis and syphilitic hepatitis following unprotected insertive oral sexual intercourse: case report. Acta Dermatovenerol Croat 2010;18:276-278.

[45] Ibáñez M, Varela M, Rodríguez-Peláez M, Mancebo A, García-Mayor MA, Pereira R, et al. Luetic hepatitis. An emerging entity. Gastroenterol Hepatol 2009;32:610-613. doi: 10.1016/j.gastrohep.2009.05.001.

[46] Hosein SR. Syphilis can attack the liver in HIV-positive men. Canadian AIDS Treatment Information Exchange 2009. Available from: http://www.thebody. com/content/art51480.html.

[47] Doyle RJ, Desai M, White J. Response to Crum-Cianflone et al., syphilitic hepatitis among HIV-infected patients. Int J STD AIDS 2009;20:739-740. doi: 10.1258/ijsa.2009.009297.

[48] Crum-Cianflone N, Weekes J, Bavaro M. Syphilitic hepatitis among HIVinfected patients. Int J STD AIDS 2009;20:278-284. doi: 10.1258/ijsa. 2008.008324.

[49] Béraud G, Pierre-François S, Theodose R, Desbois N, Abel S, Liautaud B, et al. Anicteric cholestasis among HIV infected patients with syphilis. Scand J Infect Dis 2009;41:524-527. doi: 10.1080/00365540902798325.

[50] Albandea Moreno C, Aguilar Urbano VM, Rivera Irigoin R, Gonzalo Marín J, Rosales Zabal JM, Moreno García A, et al. Syphilitic hepatitis: case report. Rev Esp Enferm Dig 2009;101:813-814. doi: 10.4321/S1130-01082009001100011.

[51] Noto P, Del Nonno F, Licci S, Chinello P, Petrosillo N. Early syphilitic hepatitis in an immunocompetent patient: really so uncommon? Int J STD AIDS 2008; 19:65-66. doi: 10.1258/ijsa.2007.007037.

[52] Noto P, Boumis E, Passarelli F, Licci S. An old disease makes a comeback. Liver Int 2008;28:1417. doi: 10.1111/j.1478-3231.2008.01771.x.

[53] Tanyel E, Tașdelen Fişgin N, Sarikaya Genç H, Tülek N. A case of secondary syphilis with hepatitis. Mikrobiyol Bul 2007;41:291-296.

[54] Lo JO, Harrison RA, Hunter AJ. Syphilitic hepatitis resulting in fulminant hepatic failure requiring liver transplantation. J Infect 2007;54:e115-e117. doi: $10.1016 /$ j.jinf.2006.07.005.
[55] Keskin S, Sayali E, Keskin E, Celebi A, Senol EG, Gürler M, et al. A case of syphilis investigated due to high liver enzymes. Turk J Gastroenterol 2007; 18:62-63.

[56] Greenstone CL, Saint S, Moseley RH. Clinical problem solving. A hand-carried diagnosis. N Engl J Med 2007; 356:2407-2411. doi: 10.1056/NEJMcps062271.

[57] Camara B, Kamar N, Bonafe JL, Danjoux M, Suc B, Rostaing L. Syphilis hepatitis and liver transplantation. Med Mal Infect 2007;37:121-123. doi: 10. 1016/j.medmal.2006.11.012.

[58] Camara B, Kamar N, Bonafe JL, Danjoux M, Suc B, Rostaing L. Syphilisrelated hepatitis in a liver transplant patient. Exp Clin Transplant 2007;5: 724-726.

[59] Wolf SC, Kempf VA, Tannapfel A, Petersen P, Risler T, Brehm BR. Secondary syphilis after liver transplantation: case report and review of the literature. Clin Transplant 2006;20:644-649. doi: 10.1111/j.1399-0012.2006.00531.x.

[60] Mandache C, Coca C, Caro-Sampara F, Haberstezer F, Coumaros D, Blicklé F, et al. A forgotten aetiology of acute hepatitis in immunocompetent patient: syphilitic infection. J Intern Med 2006;259:214-215. doi: 10.1111/j.13652796.2005.01596.x

[61] Ishikawa M, Shimizu I, Uehara K, Fujiwara S, Shiraishi T, Yamamoto H, et al. A patient with early syphilis complicated by fatty liver who showed an alleviation of hepatopathy accompanied by jaundice after receiving anti-syphilitic therapy. Intern Med 2006;45:953-956. doi: 10.2169/internalmedicine.45. 1746.

[62] Sabbatani S, Manfredi R, Attard L, Salfi N, Chiodo F. Secondary syphilis presenting with acute severe hepatic involvement in a patient with undiagnosed HIV disease. AIDS Patient Care STDS 2005;19:545-549. doi: 10.1089/apc.2005. 19.545.

[63] Cooper C, MacPherson P, Angel JB. Liver toxicity resulting from syphilis and Jarish-Herxheimer reaction in cases of coinfection with HIV and hepatitis C virus. Clin Infect Dis 2005;40:1211-1212. doi: 10.1086/428848.

[64] Watson KM, White JM, Salisbury JR, Creamer D. Lues maligna. Clin Exp Dermatol 2004;29:625-627. doi: 10.1111/j.1365-2230.2004.01630.x.

[65] Ridruejo E, Mordoh A, Herrera F, Avagnina A, Mando OO. Severe cholestatic hepatitis as the first symptom of secondary syphilis. Dig Dis Sci 2004;49: 1401-1404. doi: 10.1023/B:DDAS.0000042237.40205.c6.

[66] Jamieson A. Deranged liver function tests in type 1 diabetes mellitus: an unusual presentation of Treponema pallidum infection. Eur J Intern Med 2003;14:113-115. doi: 10.1016/S0953-6205(02)00218-2.

[67] Ozaki T, Takemoto K, Hosono H, Miyagawa K, Akimoto S, Nishimura N. Secondary syphilitic hepatitis in a fourteen-year-old male youth. Pediatr Infect Dis ] 2002;21:439-441.

[68] Almoujahed MO, Johnson LB, Khatib R. Syphilitic hepatitis presenting with fever and inguinal lymphadenopathy without rash: a case report. Infectious Diseases in Clinical Practice 2002;11:286-287. doi: 10.1097/00019048200206000-00006.

[69] Taniguchi Y, Nakae Y, Ikoma K, Ishihara Y, Kumamoto M, Nakazawa K, et al. Subclinical syphilitic hepatitis, which was markedly worsened by a JarischHerxheimer reaction. Am J Gastroenterol 1999;94:1694-1696. doi: 10. 1111/j.1572-0241.1999.01168.x.

[70] Gschwantler M, Gulz W, Schrutka-Kölbl C, Kogelbauer G, Schober G, Bibus B, et al. Acute hepatitis as the leading symptom of secondary syphilis. Dtsch Med Wochenschr 1996;121:1457-1461. doi: 10.1055/s-2008-1043168.

[71] Shapiro MP, Gale ME. Tertiary syphilis of the liver: CT appearance. J Comput Assist Tomogr 1987;11:546-547. doi: 10.1097/00004728-198705000-00038.

[72] Cronin EB, Williams WH, Tow DE. Radionuclide imaging in a case of tertiary syphilis involving the liver and bones. J Nucl Med 1987;28:1047-1051.

[73] Haburchak DR, Davidson H. Anorectal lesions and syphilitic hepatitis. West ] Med 1978;128:64-67.

[74] Fehér J, Somogyi T, Timmer M, Józsa L. Early syphilitic hepatitis. Lancet 1975;2:896-899. doi: 10.1016/S0140-6736(75)92129-7.

[75] Bhowmick BK, Simpsom B, Way SP. Secondary syphilis presenting jaundice. Postgrad Med J 1975;51:412-416. doi: 10.1136/pgmj.51.596.412.

[76] Le Clair RA. Early syphilitic hepatitis. A possible case. Br ] Vener Dis 1971; 47:212. doi: $10.1136 /$ sti.47.3.212

[77] Pierce HE. Early acute syphilitic benign hepatitis; a case report. ] Natl Med Assoc 1953;45:219-220.

[78] Nicol CS, Terry RB. Late syphilis of the liver treated with penicillin. Br J Vener Dis 1951;27:20-22. doi: 10.1136/sti.27.1.20.

[79] Lamps LW. Hepatic Granulomas: A Review With Emphasis on Infectious Causes. Arch Pathol Lab Med 2015;139:867-875. doi: 10.5858/arpa. 2014-0123-RA. 